\title{
Studies on the Pathogenesis of Lipoatrophic Diabetes: A Case of Congenital Systemic Absence of Adipose Tissue Associated with Insulin-Resistant Diabetes Mellitus and Hepatosplenomegaly
}

\author{
J. Taton, B. Malczewski and A. Wisniewska \\ III Department of Internal Medicine, Warsaw Medical School Head: Prof. A. Czyzyk Diabetologic Clinical Research \\ Center in Krynica, Scientific Consultant: Ass. Prof. J. Taton. \\ Received: May 2, 1972, accepted: May 19, 1972
}

\begin{abstract}
Summary. A case of coexisting lipoatrophy, hyperlipemia, insulin-resistant diabetes mellitus and hepatosplenomegaly (fatty liver and early cirrhosis, as shown by biopsy) is described. Investigations attempting to explain the pathogenesis of these disturbances are presented. From the urine of the patient both the insulin antagonizing (Louis' factor) and lipid mobilizing substance (Chalmers' factor) were extracted. Injection of these extracts obtained from the patient's urine induced 1) insulin resistance, 2) hyperlipemia and 3) fatty infiltration of the liver in mice. The pathogenetic hypothesis that humoral factors cause a constant increase in lipolysis and therefore prevent triglyceride storage in the adipocytes is discussed.
\end{abstract}

Etude sur la pathogénie du diabète lipoatrophique: un cas d'absence systémique congénitale de tissu adipeux associée à un diabète sucré insulino-résistant et à une hépatosplénomégalie

Résumé. Les auteurs décrivent un cas de lipoatrophie, d'hyperlipémie, de diabète sucré insulino-résistant et d'hépato-splénomégalie (foie gras et début de cirrhose hépatique, comme le montre la biopsie). Les investigations pour tenter d'expliquer la pathogénie de ces troubles sont rapportées. La substance antagonisant l'insuline (facteur Louis) ainsi que la substance mobilisant les lipides (facteur Chalmers) ont été extraites de l'urine de la patiente. En injectant ces extraits obtenus des urines de la patiente, on a provoqué expérimentalement chez la souris 1) une insulino-résistance, 2) une hyperlipémie et
3) une infiltration graisseuse du foie. L'hypothèse de facteurs humoraux provoquant l'augmentation constante de la lipolyse et par conséquent empêchant le stockage des triglycérides dans les adipocytes est discutée en tant que mécanisme pathogénique dans le diabète lipoatrophique.

Untersuchungen über die Pathogenese des lipoatrophischen Diabetes: ein Fall von kongenitalem, systematischem Schwund des Fettgewebes mit insulinresistentem Diabetes mollitus und Hepatosplenomegalie

Zusammenfassung. Es wird über einen Fall von Lipoatrophie, verbunden mit Hyperlipämie insulinresistentem Diabetes mellitus und Hepatosplenomegalie (bioptisch: Fettleber mit beginnender Cirrhose) berichtet. Untersuchungen zur Aufklärung der Pathogenese dieser Störungen werden vorgelegt, Aus dem Harn der Patientin wurden sowohl die Insulin-antagonistische (Louis Falktor) wie auch die lipidmobilisierende Substanz (Chalmers Faktor) extrahiert. Injektionen dieser Extrakte aus dem Harn der Patientin führten bei Mäusen 1) zu Insulinresistenz, 2) zu Hyperlipämie und 3) zur Fettinfiltration der Leber. Die pathogenetische Hypothese, wonach humorale Faktoren eine konstante Erhöhung der Lipolyse verursachen und damit die Ablagerung von Triglyzeriden in den Adipozyten, verhindern, wird diskutiert.

Key words: Hyperlipaemia, Lipid Mobilizing Substance, Lipoatrophic diabetes, Louis factor, Insulin resistance, Urinary polypeptides, chalmers faktor.
The purpose of this paper is to present a case of lipoatrophic diabetes mellitus and to discuss the results of its pathophysiological investigation.

\section{Clinical data}

In a female, J.M., born in 1953 (case record No. $405 / 12961 / 67$ ), a progressive loss of adipose tissue has been observed since the age of 18 months. Initially it was restricted to the subcutaneous tissue of the calves, palms, cheeks and buttocks. By the age of 2 years the whole subcutaneous adipose tissue was already markedly atrophied. Polydipsia was observed from the age of 4 years. In 1967, when the patient was 14 years old, diabetes mellitus and hepatomegaly were recognized.
At this time treatment with $100 \mathrm{u}$. of insulin daily was started but this did not influence significantly the average daily glycaemia and glucosuria. No further increase in body weight was noticed. The patient's family history revealed that her maternal great-uncle suffered from maturity onset diabetes mellitus, but five siblings are healthy.

Clinical examination. Height $-152 \mathrm{~cm}$, weight $41 \mathrm{~kg}, \mathrm{BP}-130 / 80 \mathrm{~mm} \mathrm{Hg}$. Skin dry, atrophic and flaccid. Numerous xanthomata on both elbows and on the posterior, upper areas of the thighs. Subcutaneous adipose tissue markedly atrophied. The absence of adipose tissue set in relief the muscles and subcutaneous veins. In the pubic area the hair was scanty with a distribution of the female type. The liver was greatly 


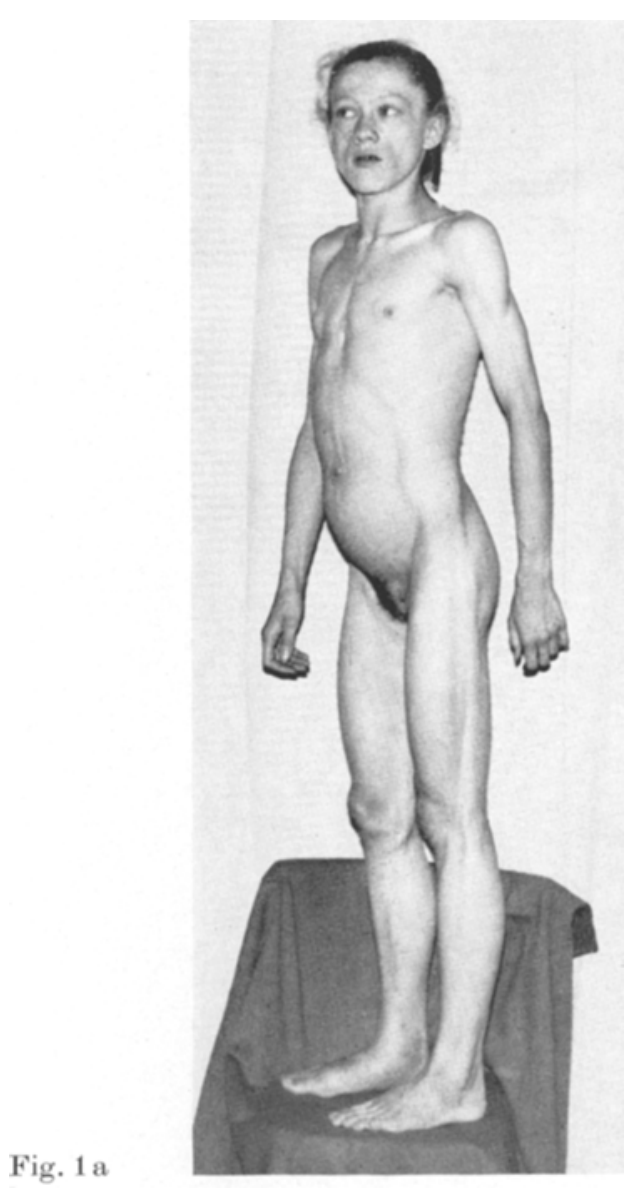

Fig. $1 \mathrm{a}$

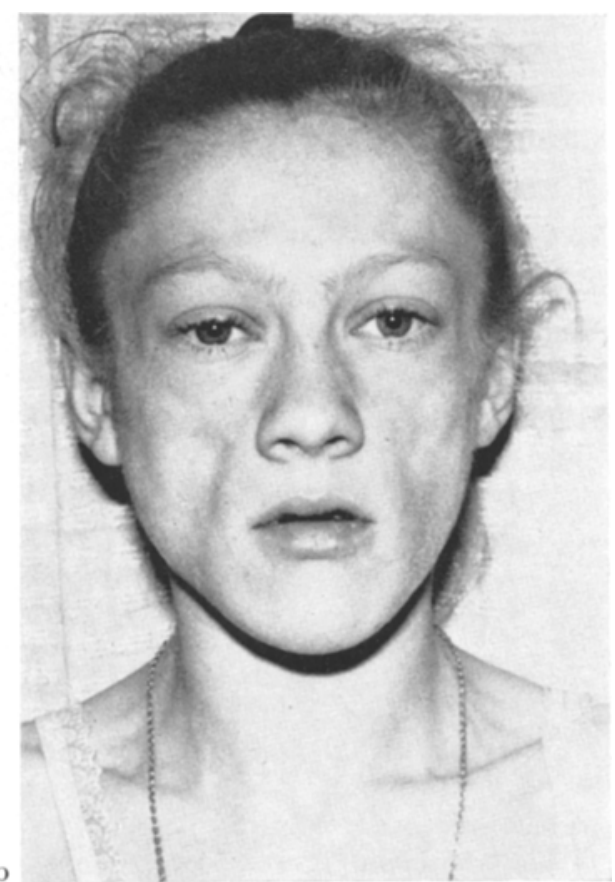

enlarged (to the transverse umbilical line) and hard. The spleen protruded $3 \mathrm{~cm}$ from the costal margin.

Routine laboratory investigations are presented in Table 1.

Liver biopsy disclosed extensive vacuolar degeneration of cell nuclei, fatty degeneration of the cytoplasm and dilatation and fibrosis of the portal spaces, which suggested early cirrhosis. Peripheral blood vessels: no changes were observed by funduscopy. Capillaroscopic, oscillometric, photoplethysmographic, polarographic and reangiographic studies of the arterioles and capillaries revealed functional abnormalities. Electromyography; slight changes suggesting a discrete involvement of the peripheral motor neurons. This finding confirmed the clinical diagnosis of diabetic neuropathy. The histochemical investigations of the skeletal muscle biopsy specimens gave normal results. The muscle fibres were of normal size (up to $40 \mu$ in diameter) without any evident structural changes and the arrangement of fibres in bundles was normal. The serum level of creatine phosphokinase was $0.05 \mathrm{u}$. [9].

Clinical metabolic investigations. The standard diet administered during the studies contained $400 \mathrm{~g}$ of carbohydrates, $80 \mathrm{~g}$ of protein and $60 \mathrm{~g}$ of fat (Table 2).

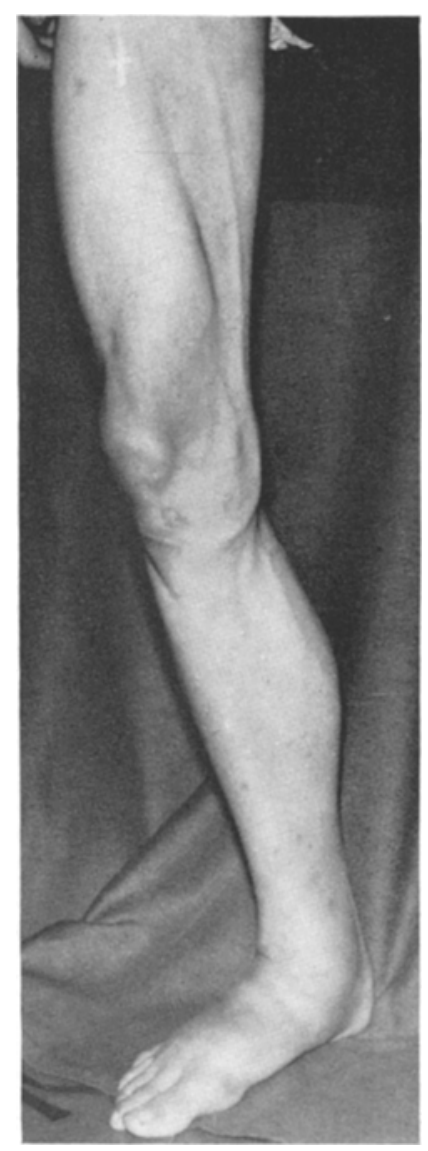

Fig. 1. a) The silhouette of the patient. b) The face with lipoatrophy. c) The outlines of the veins and muscles on the surface of the calves are distinctly visible; they are not covered by adipose tissue 
Carbohydrate metabolism. The 24-hour blood glucose (11) measurements during treatment with crystalline insulin - $48 \mathrm{u}$. in the morning, and $40 \mathrm{u}$. in the afternoon - Were: $-7 \mathrm{~h}-232,10 \mathrm{~h}-236,12 \mathrm{~h}$ $-280,15 \mathrm{~h}-300,18 \mathrm{~h}-240,22 \mathrm{~h}-296,0 \mathrm{~h}-264$, $3 \mathrm{~h}-256 \mathrm{mg} \%$. The blood glucose after i.v. administration of $1.00 \mathrm{~g}$ of sodium tolbutamide was as follows: fasting - 304, after $10 \mathrm{~min}-324,20 \mathrm{~min}-$ $198,30 \mathrm{~min}-290,45 \mathrm{~min}-318,60 \mathrm{~min}-304 \mathrm{mg} \%$.

Blood glucose and free fatty acid levels (20) after intravenous insulin administration were:

\begin{tabular}{|c|c|c|}
\hline Time & $\begin{array}{l}\text { Blood } \\
\text { glucose } \\
\text { in } \mathrm{mg} \%\end{array}$ & $\begin{array}{l}\text { FFA in } \\
\mu \mathrm{Eq} / 1\end{array}$ \\
\hline Fasting & 206 & 700 \\
\hline $30 \mathrm{~min}$ after $100 \mathrm{u}$. of insulin i. $\mathrm{v}$. & 234 & 760 \\
\hline $60 \mathrm{~min}$ & 180 & 760 \\
\hline
\end{tabular}

After $60 \mathrm{~min}$ a repeated dose of $100 \mathrm{u}$. of insulin was administered i.v.

$\begin{array}{lll}90 \mathrm{~min} & 148 & 648 \\ 120 \mathrm{~min} & 134 & 353\end{array}$

Blood glucose level, FFA and insulin-like serum activity (ILA) after oral administration of $100.0 \mathrm{~g}$ of glucose were as follows:

$\begin{array}{rllll}\text { Time } & \begin{array}{l}\text { Blood } \\ \text { glucose } \\ \text { in } \mathrm{mg}^{\circ} \%\end{array} & \begin{array}{l}\text { FFA in } \\ \mu \mathrm{Eq} / 1\end{array} & \begin{array}{l}\text { ILA } \\ \mu \mathrm{m} / \mathrm{ml}\end{array} & \begin{array}{l}\text { normal } \\ \text { values }\end{array} \\ \text { Fasting } & 330 & 1330 & 750 & 310 \pm 140 \\ 30 \mathrm{~min} & 380 & 1330 & 610 & 430 \pm 130 \\ 60 \mathrm{~min} & 346 & 1000 & & \\ 90 \mathrm{~min} & 426 & 1000 & & \\ 120 \mathrm{~min} & 336 & 660 & & 330 \pm 160 \\ 180 \mathrm{~min} & 362 & 800 & 850 & \end{array}$

ILA was determined in serum diluted $1: 15$ in our own modification $[29,30]$ of the method of Ball-Merrill [2].

Lipid metabolism. Blood lipids: total lipids [10, 10a] - $2000 \mathrm{mg} \%$, phospholipids [7] - $248 \mathrm{mg} \%$, cholesterol [22] - $340 \mathrm{mg} \%$, triglycerides [10] $1309 \mathrm{mg} \%$. The serum lipolytic activity $[19,19 \mathrm{a}]$ after administration of heparin (25 mg) was $24 \mathrm{u}$. (normal value up to 25 u.). Electrophoretic separation of serum lipoproteins (26); alpha lipoproteins - 7.1\% (normal values $27-33 \%$ ); beta lipoproteins - $67.2 \%$ (normal values $50-60 \%$ ), "tail" (chylomicrons) $25,7 \%$ (normal values $13-17 \%$ ).

Protein metabolism. Serum: paper electrophoresis (21) - total proteins - $6.6 \mathrm{~g} \%$, albumins - $48.2 \%$, globulins alpha $a_{1}-2.6 \%$ globulins alpha $a_{2}-7.0 \%$, globulins beta $-17.6 \%$, globulins gamma $-24.6 \%$. Chromatographic analysis of the urine (28) revealed the presence of glycine, alanine, glutamine, leucine and histidine. These aminoacids were present in the urine in amounts considerably exceeding normal ones.
Therapy. Effects of different types of treatment are shown in Table 2.

Table 1. Results of routine laboratory examinations
Blood

ESR

Blood cell count

Bilirubin

Urea

Uric acid

Prothrombin index

Serum

Sodium

Potassium

Calcium

Phosphorus

Iron

Enzymes

Aminotransferase-aspartic - $54 \mathrm{u}$.

Aminotransferase-alanine - $86 \mathrm{u}$.

Aldolase (10)

Phosphatase alk.

Phosphatase acid

Urine

Daily volume

$24 \mathrm{~h}$ glucosuria

Ketonuria

Albuminuria

Urobilinogen

Addis test

GFR

Tubular reabs.

Cultures

17-KS/24 h $(3,3$ a)

17-OHCS/24 h (27)

Functional tests

BSP retention, $45 \mathrm{~min}$

BMR

131 I thyroid uptake, $6 \mathrm{~h}$

$131 \mathrm{I}$ thyroid uptake, $24 \mathrm{~h}$

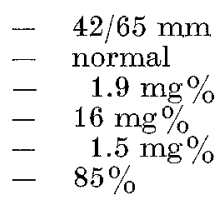

- $139.1 \mathrm{mEq} / \mathrm{l}$

- $\quad 4.1 \mathrm{mEq} / \mathrm{l}$

- $\quad 4.2 \mathrm{mEq} / 1$

- $\quad 2.1 \mathrm{mEq} / \mathrm{l}$

$-\quad 74 \gamma \%$

- $\quad 38.5$ u (normal $<3.8$ u)

$-\quad 1.5-3.51$

- $100-250 \mathrm{~g}$

$-0$

$-0$

- normal

- $90 \mathrm{ml} / \mathrm{min}$

$-\quad 97.6 \%$

- no bacteria

- $4.8 \mathrm{mg}$

- $\quad 3.4 \mathrm{mg}$

$-35 \%$
$-+35 \%$
$-\quad 11 \%$
$-\quad 18 \%$ (decreased)
- $\quad 5.6$ Bodansky u.

- $1.2 \mathrm{u}$.

\section{Animal experiments}

Isolation of the factor antagonistic to insulin from the urine according to the procedure of Louis et al. $[14,16$, 18]. The urinary extract was bioassayed on intact mice. First the minimal dose of insulin causing hypoglycaemic shock in mice fasting over $12 \mathrm{~h}$ was determined. In the control group it ranged from 0.06 to $0.15 \mathrm{u}$. of insulin per animal. The test involved administration of twice the minimal dose of insulin causing hypoglycaemic shock to mice injected intraperitoneally, $24 \mathrm{~h}$ earlier, with $1 \mathrm{ml}$ of the urinary extract suspension. The extract obtained from the urine was suspended in Krebs buffer $(\mathrm{pH}=7.4)$. The proportions were as follows: extract abtained from 11 of urine was suspended in $10 \mathrm{ml}$ of buffer solvent. The injection of $1 \mathrm{ml}$ of such a preparation prevented a decrease of glyeaemia and hypoglycaemic symptoms after insulin administration in all the treated mice.

In contrast, in the control group of mice injected with $1 \mathrm{ml}$ of $0.9 \% \mathrm{NaCl}$, hypoglycaemic symptoms after insulin injection occurred in all animals (Table 3 ). 
Isolation of the lipid mobilizing substance (LMS). LMS was isolated from the patient's urine 1) after $48 \mathrm{~h}$ of total fast and 2) during feeding with a standard diet - according to the method described by Chalmers [6]. In each type of experiment the extracts obtained from 31 of urine were suspended in $15 \mathrm{ml}$ of Krebs buffer and used for biological tests on mice. The mice were injected with $0.9 \%$ saline 1 ); with the extracts from urine of 2) fasting and 3) fed healthy aubjects; and from the patient's urine 4) after $48 \mathrm{~h}$ of fast and 5) during feeding with a standard diet. despite the increase in the insulin dosage and while eating a high caloric diet could indicate a defect in the storage of the calories in the form of fat. The increase in the caloric value of the diet resulted in increasing glucosuria, in spite of augmentation of the insulin dosage. This disorder became clinically noticeable when the patient was 18 months old. As in other cases the lipoatrophy was not observed immediately after birth [25]. The patient's fasting blood ILA levels were slightly elevated. $30 \mathrm{~min}$ after an oral glucose load, however, the ILA value was lower than the fasting one,

Table 2. Observations during different types of treatment

\begin{tabular}{|c|c|c|c|c|c|c|}
\hline$\overline{\text { Treatment }}$ & $\begin{array}{l}24 \mathrm{~h} \\
\text { glycaemia } \\
\text { mg\% } \\
\end{array}$ & $\begin{array}{l}24 \mathrm{~h} \\
\text { glucosuria } \\
\mathrm{g}\end{array}$ & $\begin{array}{l}\text { Choles- } \\
\text { terol } \\
\mathrm{mg} \%\end{array}$ & $\begin{array}{l}\text { FFA } \\
\mu \mathrm{Eq} / 1\end{array}$ & $\begin{array}{l}\text { ketones in } \\
\text { blood }(21) \\
\operatorname{mg} \%\end{array}$ & $\begin{array}{l}\text { Body } \\
\text { weight } \\
\mathrm{kg}\end{array}$ \\
\hline No insulin for 30 days & $\begin{array}{r}7 \mathrm{~h}-240 \\
10 \mathrm{~h}-326 \\
12 \mathrm{~h}-286 \\
15 \mathrm{~h}-304 \\
18 \mathrm{~h}-260 \\
22 \mathrm{~h}-296 \\
0 \mathrm{~h}-380 \\
3 \mathrm{~h}-222\end{array}$ & $140-260$ & 340 & 1330 & $5.1-8.1$ & 41.0 \\
\hline $\begin{array}{l}\text { Crystalline insulin twice } \\
\text { daily. } 200 \mathrm{u} .-10 \text { days }\end{array}$ & $\begin{array}{r}7 \mathrm{~h}-268 \\
15 \mathrm{~h}-176 \\
22 \mathrm{~h}-264\end{array}$ & $120-240$ & 320 & 900 & 4.2 & 41.6 \\
\hline $\begin{array}{l}\text { Crystalline insulin } 240 \mathrm{u} \text {. } \\
\text { twice daily }+ \text { Dexamethasone } \\
6 \mathrm{mg}-10 \text { days }\end{array}$ & $\begin{array}{r}7 \mathrm{~h}-325 \\
15 \mathrm{~h}-240 \\
22 \mathrm{~h}-228\end{array}$ & $110-250$ & 335 & $\mathbf{1 3 6 0}$ & 6.2 & 42.4 \\
\hline $\begin{array}{l}\text { Crystalline insulin } 240 \mathrm{u} \text {. twice } \\
\text { daily thyroidea sicca } 0.2 \mathrm{mg} \\
\text { twice daily }-30 \text { days }\end{array}$ & $\begin{array}{r}7 \mathrm{~h}-242 \\
15 \mathrm{~h}-216 \\
22 \mathrm{~h}-232\end{array}$ & $80-180$ & 276 & 1300 & 5.1 & 42.9 \\
\hline $\begin{array}{l}\text { Tolbutamide } 1.5 \mathrm{~g} \text { daily } \\
-20 \text { days }\end{array}$ & $\begin{array}{r}7 \mathrm{~h}-258 \\
15 \mathrm{~h}-302 \\
22 \mathrm{~h}-286\end{array}$ & $64-210$ & 262 & 1280 & 4.8 & 41.2 \\
\hline $\begin{array}{l}\text { Phenformin } 100 \mathrm{mg} \text { daily } \\
-20 \text { days }\end{array}$ & $\begin{array}{r}7 \mathrm{~h}-246 \\
15 \mathrm{~h}-262 \\
22 \mathrm{~h}-302\end{array}$ & $80-160$ & 276 & 1120 & 5.8 & 42.0 \\
\hline $\begin{array}{l}\text { Crystalline insulin } 280 \mathrm{u} \text {, twice } \\
\text { daily, diet: } 500 \mathrm{~g} \text { of } \mathrm{CHO} \text {, } \\
100 \mathrm{~g} \text { of protein and } 100 \mathrm{~g} \text { of } \\
\text { fat }-14 \text { days }\end{array}$ & $\begin{array}{r}7 \mathrm{~h}-256 \\
15 \mathrm{~h}-219 \\
22 \mathrm{~h}-272\end{array}$ & $160-390$ & 320 & 1180 & 5.4 & 41.8 \\
\hline
\end{tabular}

a During all types of studies a standard diet $400 \mathrm{~g}$ of $\mathrm{CHO}, 80 \mathrm{~g}$ of protein, $60 \mathrm{~g}$ of fat, was fed.

The comparisons of the blood FFA levels and the total lipid contents in the liver of mice injected with $0.9 \%$ saline, control urinary extracts and the LMS extracts obtained from the patient's urine showed interesting differences in the activity of tested extracts. The results of these experiments are presented in Table 4.

Sections of liver from mice receiving LMS from the patient's urine were stained with Sudan III and showed more numerous lipid deposits compared with the controls.

\section{Discussion}

In this patient the relative unresponsiveness of the blood glucose to marked changes in the daily insulin dose was striking. Keeping a constant body weight suggesting an abnormal response of the pancreatic islets.

The influence of such conditions as hyperfunction of thyroid and adrenal cortex was clinically excluded. Hamvi [8] observed normal secretion of growth hormone in a patient with lipoatrophic diabetes.

The results of the animal experiments with the urinary extracts from the patient's urine confirm the finding of Louis et al. [15], who in 1963, obtained the insulin antagonizing extract from the urine of 4 lipoatrophic diabetics, as well as from 1 patient with maturity onset, insulin resistant, diabetes mellitus. Injection of this extract in healthy volunteers and also in dogs, caused transitory decrease in glucose tolerance and relative resistance to insulin. The polypeptides found in urinary extracts as prepared by Louis did not show any chemical or physiological properties of 
These biological effects indicate the strong lipid mobilizing properties of the extract. It is of interest that the biological activity of LMS from the patient's urine was strikingly high compared with extracts obtained from the urine of healthy subjects in fasting conditions and that this activity did not disappear after feeding, as it did in healthy subjects. The latter observation confirms the earlier findings of Chalmers concerning the possibility of isolating LMS from the urine of lipoatrophic diabetics.

In the case under study, 2 kinds of urinary extracts were obtained: one of them diminishing the responsiveness of mice to exogenous insulin (Louis' type of extract), the other increasing the FFA concentration. in blood and TG liver content as bioassayed on mice (Chalmers' type of extract).

The possibility of inducing the essential components of the lipoatrophic diabetes 1) hyperlipemia, 2) fatty infiltration of the liver, 3) insulin-resistance - in normal mice injected with the polypeptide-containing extracts of the patient's urine suggests that the essential role in the pathogenesis of this syndrome may be attributed to humoral factors. The pathogenetic polypeptides are probably present in the blood and excreted in the urine. They are probably responsible for the marked stimulation of lipolysis within the adipose tissue of the human as well as of the experimental animals.

The biochemical mechanism of these changes, the source and the chemical characteristics of pathogenic substances are far from being clear. Most interesting was the finding of both the Louis' and Chalmers' factors in the investigated case. The separate appearance of these factors has already been described. Their common appearance has been found probably for the first time. It is not possible to determine which of them is of primary importance and what their mutual relationship is. It is possible that cases of lipoatrophic diabetes are pathogenetically heterogeneous.

\section{References}

1. Aarseth, S.: Lipoatrophic diabetes. Diabetologia, 3, 535, (1967).

2. Ball, E., Merrill, M.: A method for insulin assay. Bioch. Ztschr. 69, 596-608 (1961).

3. Bonder, F.: Oznaczanie 17-ketosterydow w moczu. Post. Hig. Med. Dosw. 4, 211-227 (1953).

3a. Drekter, I.J., Heisler, A., Scism, G.R., Stern, S., Pearson, S., Mc Gavack, T.H.: The determination of urinary steroids. I. Preparation of pigment free extracts and a simplified procedure for the estimation of total 17-ketosteroids. J. clin. Endocr., 12, 55 (1952).

4. Chalmers, T.M.: Lipid-mobilizing activity during fasting. In: Handbook of Physiology, Section 5, Adipose Tissue. Washington: Amer. Physiol. Soc. Ed., 1965.

5. - Pawan, G.L.S., Kekwick, A.: Fat-mobilizing and ketogenic activity of urine extracts, relation to corticotrophin and growth hormone. Lancet 1960 II, $6-9$.
6. - Kekwick, A., Pawan, G.L. S. : Fat-mobilizing activity of human urine extract. Amer. J. clin. Nutr. 8, $728-732(1960)$.

7. Fiske, C.H., Subbarow, Y.: The colorimetric determination of phosphorus. J. biol. Chem. 66, 375-379 (1925).

8. Hamvi, J.G., Kruger, A.T., Eymontt, H.M., Scarpelli, G.D., Gwimp, G., Byron, R.: Lipoatrophic diabetes. Diabetes 15, 262-268 (1966).

9. Hughes, B.P.: A method for the estimation of serum creatine kinase and its use in comparing creatine kinase and aldolase activity in normal and pathological sera. Clin. chim. Acta 7, 597-603 (1962).

10. Ignatowska, H., Michajlik, A.: Szyblka metoda oznaczania lipidow calkowitych w surowicy lub osoczu. Pol. Tyg. lek. 13, 1037-1038 (1958).

10a. Lambert, M., Neish, A.C.: Rapid method for estimation of glycerol in fermentations solutions. Canad. J. Res. 28, 83 (1945).

11. King, E.J.: Microanalysis in medical biochemistry. London, 1947.

12. Kruger, F.A., Carhart, J.M., Anstad, R.A.: The glucose-fatty acid cycle and the liver. J. Lab. clin. Med. 64, 876-876 (1964).

13. Lawrence, R.D.: Lipodystrophy and hepatomegaly with diabetes, lipemia, and other metabolic disturbances. Lancet $1946 \mathrm{I}, 724-731,773-775$.

14. Louis, L.H., Conn, J.W., Minick, M.C. : Lipoatrophic diabetes. Isolation and characterisation of an insulin antagonist from urine. Metabolism, 12, 867-886 (1963).

15. - - - A Diabetogenic Polypeptide from Bovine Adenohypophysis Similar to that Excreted in Lipoatrophic Diabetes. Metabolism 15, 308-324 (1966).

16. - Lipoatrophic Diabetes: An Improved Procedure for Isolation and Purification of a Diabetogenic Polypeptide from Urine. Metabolism 18, 545-556 (1969).

17. - Conn, J.W.: A Urinary Diabetogenie Peptide in Proteinuric Diabetic Patients. Metabolism. 18, 556569 (1969).

18. - Minick, M.C.: Isolation of an insulin antagonist from urine of patients with lipoatrophic diabetes. J. Lab. clin. Med. 60, 995-996 (1962).

19. Lukasik, S., Orłowski, M.: O metodach oznaczania aktywności lipazy lipoproteinowej we krwi. Pol. Tyg. lek. 13, 1643-1647 (1958).

19a. Kraupp, O. and cow.: Kinetik und Substratabhängigkeit der Trioleinspaltung in Rattenplasma nach Heparinverabreichung. Biochem. Zeitschr. 301, 328 (1956).

20. Mosinger, E.: Photometric adaptation of Dole's microdetermination of free fatty acids. J. Lipid Research 6, 157-159 (1965).

21. Predteczenskij, E. W.: Metody badan laboratoryjnych. Warszawa: PZWL, 1953.

22. Searcy, R.L., Berquist, L.M.: The determination of Cholesterol directly upon acetone-ethanol filtrates. Amer. J. Med. Technology 25, 237-242 (1959).

23. Schwartz, R., Schafer, I. A., Renold, A.E.: Generalized. lipoatrophy, hepatic cirrhosis, disturbed carbohydrate metabolism and accelerated growth (lipoatrophic diabetes). Amer. J. Med. 28, 973-985 (1960).

24. Seip, M. : Lipodystrophy and gigantism with associated endocrine manifestations. Acta Paediatr. (Stockh.) 48, 555-574 (1959).

25. Senior, B., Gellis, G.S. : The syndromes of total and of partial lipodystrophy. Pediatrics, 33, 1157-1175 (1960).

26. Shwahn, B.: A micromethod for the determination of 
serum lipids after electrophoretical separation on filter paper. Scand. J. clin. Lab. Invest. 5, Suppl. 9, $44-79$ (1953).

27. Silber, R.H., Porter, C.C.: The determination of 17,21-dihydroxy-20-ketosteroids in urine and plasma. J. biol. Chem., 210, 923 -. 932 (1954).

28. Smith, J.: Chromatographic and electrophoretic technic. $40-65,82-144$. London: Hahneman and W. Medical Books LiTD, 1962.

29. Tatoń, J., Wiśniewska, A.. : Fizjologiczna charakterystyka insulinopodobnej aktywności surowicy krwi (ILA). VI Zjazd Pol. Tow. Endokryn., 30-31 May 1 June, 1968.
30. - Ceremuzynśki, L., Wiśniewska, A.: Zaburzenia przemiany węglowodanowej w ostrym okresie zawału serca. Pol. Arch. Med. Wewn., 43, 1579-1583 (1969).

31. Weil, R., De Witt Stetten jr.: The urinary excretion of a fatmobilizing agent. J. biol. Chem. 168, 129-133 (1947).

Dr. med. J. Taton

IITrd Dept. of Internal Medicine

Warszawa Medical School

Lindleya 4

Warszawa

Poland 